\title{
Kesalahan Mahasiswa Pendidikan Matematika dalam Menyelesaikan Masalah Fungsi dan Persamaan Polinomial
}

\author{
Anik Rizka Rahmawati ${ }^{1}$, Sudirman ${ }^{2}$, Rustanto Rahardi ${ }^{3}$ \\ 1, 2, 3 Program Studi Pascasarjana Pendidikan Matematika, Fakultas Sains dan Teknologi, Universitas Negeri Malang, \\ Jl. Semarang No. 5, Sumbersari, Lowokwaru, Kota Malang, Indonesia \\ anik.rizka96@gmail.com
}

\begin{abstract}
The lack of strong mastery of students' concepts of the material being studied results in the emergence of misunderstandings or errors in solving mathematical problems. Describing the errors of Mathematics Education students in solving problems of functions and polynomial equations in terms of the Kastolan error type is the purpose of this study. The type of research used is descriptive qualitative research. The importance of this research on student errors can be a reference to the extent of understanding and mastery of students' concepts of the material that has been studied. Four subjects were selected by purposive sampling based on the results of the work with incomplete completion steps or indicating an error. The instruments used in this study were researchers, test sheets, and interview guidelines. The results of this study indicate that the highest error made by students lies in the technical error with a percentage of $43.9 \%$ and is categorized as a serious error. The second error in the category of moderately severe error is a conceptual error with a percentage of $39.4 \%$. The third error is a procedural error with a percentage of $16.7 \%$ and is included in the category of minor error.
\end{abstract}

Keywords: Kastolan Error Type, Polynomial Function, Polynomial Equation

\begin{abstract}
Abstrak
Kurang kuatnya penguasaan konsep mahasiswa terhadap materi yang dipelajari mengakibatkan munculnya kesalahpahaman atau kesalahan dalam menyelesaikan masalah matematika. Mendeskripsikan kesalahan mahasiswa Pendidikan Matematika dalam menyelesaikan masalah fungsi dan persamaan polinomial ditinjau dari tipe kesalahan Kastolan adalah tujuan penelitian ini. Jenis penelitian yang digunakan yakni penelitian kualitatif deskriptif. Pentingnya penelitian tentang kesalahan mahasiswa dapat menjadi acuan sejauh mana pemahaman dan penguasaan konsep mahasiswa terhadap materi yang telah dipelajari. Terpilih sebanyak empat subjek secara purposive sampling berdasarkan hasil pekerjaan dengan langkah-langkah penyelesaian yang tidak lengkap atau menunjukkan adanya kesalahan. Instrumen yang digunakan pada penelitian ini adalah peneliti, lembar tes, serta pedoman wawancara. Hasil pada penelitian ini menunjukkan kesalahan tertinggi yang dilakukan mahasiswa terletak pada kesalahan teknik dengan persentase 43,9\% dan dikategorikan kesalahan berat. Kesalahan kedua dengan kategori kesalahan cukup berat ialah kesalahan konseptual dengan persentase sebesar $39.4 \%$. Kesalahan ketiga ialah kesalahan prosedural dengan persentase sebesar $16.7 \%$ dan termasuk pada kategori kesalahan ringan.
\end{abstract}

Kata kunci: Tipe Kesalahan Kastolan, Fungsi Polinomial, Persamaan Polinomial

Copyright (c) 2021 Anik Rizka Rahmawati, Sudirman, Rustanto Rahardi

$\triangle$ Corresponding author: Anik Rizka Rahmawati

Email Address: anik.rizka96@gmail.com (Jln. Joyoraharjo Gg. IX No 3 Malang)

Received 15 July 2021, Accepted 24 July 2021, Published 08 August 2021

\section{PENDAHULUAN}

Matematika merupakan salah satu mata pelajaran yang ada dalam setiap jenjang pendidikan. Hal ini menandakan begitu pentingnya matematika dipelajari sebagai dasar dari ilmu pengetahuan. Mempelajari matematika erat kaitannya dengan keteraturan antar unsur yang terorganisasi, serta konsep-konsep yang tersusun secara hierarki (Hasratuddin, 2014). Hierarki memiliki arti bertingkat dimana konsep pada materi sebelumnya akan digunakan pada materi berikutnya. Jika pada konsep-konsep dasar sebelumnya mahasiswa belum menguasai dengan baik, maka mereka akan kesulitan untuk menerima materi berikutnya. Sementara tingkatan materi juga semakin abstrak, sehingga dengan dasar yang tidak kuat akan membuat mahasiswa 
menjadi bingung. Asumsi ini didukung oleh pernyataan Romadiastri (2012) bahwa salah satu ciri ilmu matematika adalah bersifat abstrak. Semakin kompleks materi yang dipelajari menandakan semakin abstraknya materi tersebut. Oleh karena itu, dibutuhkan keterampilan, ketelitian, dan kemampuan yang telah dimilikinya sebagai usaha untuk mempelajari materi matematika berikutnya.

Tentu saja hal ini membuat banyak orang merasa kesulitan mempelajarinya, bahkan mahasiswa Pendidikan Matematika sekalipun. Kesulitan yang dirasakan oleh mahasiswa selama pembelajaran dapat diidentifikasi dari kesalahan-kesalahan yang dilakukannya. Munculnya kesalahan tersebut dapat dilihat dari ketidaktepatan hasil pekerjaan mahasiswa. Hal ini menunjukkan bahwa mahasiswa belum mampu menguasai konsep terhadap materi yang telah dipelajari. Selaras dengan pendapat Raharti \& Yunianta (2020) bahwa pemahaman konseptual terlihat saat peserta didik mengerjakan masalah yang diberikan namun merasa kesulitan jika masalah tersebut diubah. Dengan kata lain, mahasiswa dapat mengerjakan soal sesuai contoh yang diberikan pendidik namun merasa kesulitan jika diberikan soal diluar contoh (out of the box). Bersumber dari uraian di atas, kurang kuatnya pondasi tentang konsep materi sebelumnya mengakibatkan adanya kesalahpahaman atau kesalahan yang dilakukan mahasiswa pada materi berikutnya.

Bentuk kesalahan yang dilakukan oleh mahasiswa dalam menyelesaikan masalah matematika pada penelitian ini cukup bervariasi. Bentuk kesalahan tersebut dapat diketahui dengan melakukan telaah terhadap kesalahan mahasiswa dalam menyelesaikan masalah. Masalah yang diberikan dapat berupa pemberian soal latihan di akhir pembelajaran. Tidak semua soal matematika dapat dikatakan suatu masalah (Febriyanti, 2019). Belum tentu soal yang dianggap masalah bagi satu mahasiswa juga menjadi masalah bagi mahasiswa lain. Hal ini bergantung pada kemampuan dari tiap individu. Dengan menuangkan seluruh kemampuan, keterampilan, dan pemikiran individu terhadap suatu masalah dapat dijadikan alat bantu untuk memecahkan permasalahan tersebut (Jupri \& Drijvers, 2016; Arilaksmi, dkk, 2021). Pemberian masalah berupa soal latihan juga dapat dijadikan acuan bagi pendidik dalam mengevaluasi proses pembelajaran (Firdaus, dkk, 2021).

Kesalahan mahasiswa dalam menyelesaikan permasalahan matematika pada penelitian ini ditelaah dan diuraikan berdasarkan tipe kesalahan Kastolan. Terdapat tiga tipe kesalahan menurut Kastolan yakni kesalahan konseptual, prosedural, dan teknik (Noviani, 2019). Kesalahan konseptual berkaitan dengan kesalahan dalam mendefinisikan istilah, konsep, dan prinsip. Kesalahan berikutnya adalah kesalahan prosedural. Kesalahan prosedural adalah kesalahan dalam menyusun algoritma atau langkah secara sistematis untuk menjawab suatu masalah. Sedangkan kesalahan teknik merupakan kesalahan dalam menentukan hasil akhir. Indikator pada setiap tipe kesalahan dalam penelitian ini disesuaikan dengan keadaan lapangan saat mahasiswa menyelesaikan masalah fungsi dan persamaan polinomial.

Mata kuliah Pengantar Aljabar merupakan salah satu mata kuliah yang wajib ditempuh oleh seluruh mahasiswa Pendidikan Matematika pada semester 1. Materi yang dipelajari pada saat kegiatan praktik lapangan yang telah selesai dilaksanakan oleh peneliti adalah materi fungsi polinomial. Materi tersebut sebenarnya sudah pernah dipelajari oleh mahasiswa pada tingkat sebelumnya, kemudian materi tersebut dipelajari kembali lebih mendalam pada kegiatan perkuliahan. Secara implisit, pengetahuan dasar terkait 
materi fungsi polinomial telah dimiliki oleh mahasiswa. Namun karena kemampuan setiap mahasiswa beragam dan berbeda-beda, dimungkinkan akan menghadapi kendala/hambatan saat menyelesaikan soal (Ulfa \& Kartini, 2021). Kendala tersebut dapat menyebabkan terjadinya kesalahan pada hasil pekerjaan mahasiswa.

Berdasarkan hasil penelitian Musyadad (2021) menjelaskan bahwa rata-rata kesalahan konseptual yang dialami oleh mahasiswa sebesar 50\%, kemudian rata-rata kesalahan strategi atau prosedural sebesar $30 \%$, berikutnya kesalahan teknik atau hitung sebesar 20\%. Hasil penelitian tersebut mengindikasikan kemampuan mahasiswa yang belum maksimal dalam menyerap materi yang disampaikan. Berbeda dengan hasil penelitian Mauliandri \& Kartini (2020) menunjukkan bahwa kesalahan teknik merupakan kesalahan paling tinggi dengan persentase sebesar $40.4 \%$, kesalahan kedua adalah kesalahan prosedural sebesar $35.8 \%$ serta kesalahan paling ringan yakni kesalahan konseptual sebesar 23.8\%.

Kesalahan mahasiswa yang dilakukan dalam mengerjakan soal bisa mengukur sejauh mana pemahaman dan penguasaan konsep mahasiswa terhadap materi yang diberikan. Berdasarkan kesalahankesalahan yang dilakukan, dapat diulas dan dikaji lebih lanjut mengenai sumber kesalahan mahasiswa. Sumber kesalahan tersebut harus segera mendapatkan penyelesaian yang tepat sehingga tidak terjadi kesalahan secara berulang di kemudian hari. Oleh karena itu, telaah dan ulasan kesalahan mahasiswa dalam menyelesaikan masalah perlu diteliti lebih lanjut, sehingga secara khusus penelitian ini bertujuan untuk mendeskripsikan kesalahan mahasiswa Pendidikan Matematika dalam menyelesaikan masalah fungsi dan persamaan polinomial ditinjau dari tipe kesalahan Kastolan.

\section{METODE}

Penelitian ini merupakan jenis penelitian kualitatif dengan metode deskriptif. Instrumen utama dalam penelitian ini yakni peneliti sendiri dan instrumen pendukung dalam penelitian ini adalah instrumen tes, serta pedoman wawancara. Pedoman wawancara disusun berbasis tugas untuk mengkonfirmasi hasil pekerjaan tiap subjek. Instrumen tes terdiri dari tiga soal yang diberikan kepada 34 mahasiswa program studi Pendidikan Matematika yang sedang menempuh mata kuliah Pengantar Aljabar di akhir pembelajaran. Instrumen tes disajikan pada Tabel 1 berikut ini.

Tabel 1. Masalah Fungsi dan Persamaan Polinomial

\begin{tabular}{|l|l|}
\hline Soal Pertama & $\begin{array}{l}\text { Diantara fungsi dibawah ini manakah yang merupakan fungsi polinomial dan } \\
\text { manakah yang bukan fungsi polinomial? Berikan alasan. } \\
\text { a. } f(x)=x^{4}-\frac{1}{2} x^{3}-3 x^{2}+\sqrt{2} x-\epsilon \\
\text { b. } f(x)=5 x^{3}-3 x^{2}+\sqrt{2 x}-\pi\end{array}$ \\
\hline Soal Kedua & $\begin{array}{l}\text { Rani mempunyai hobi baru memelihara ikan hias. Dirumahnya terdapat } \\
\text { aquarium yang berbentuk balok. Aquarium tersebur dapat menampung air } \\
\text { yang dinyatakan dengan polinomial sebanyak } 6 x^{3}+31 x^{2}+53 x+30 \\
\text { dalam satuan } \mathrm{cm}^{3} \text {. Jika tinggi aquarium diketahui adalah }(x+2) \mathrm{cm}, \text { maka } \\
\text { tentukan panjang dan tinggi aquarium! }\end{array}$ \\
\hline
\end{tabular}




\begin{tabular}{|c|l|}
\hline Soal Ketiga & $\begin{array}{l}\text { Diberikan persamaan berikut } 3 x^{4}-x^{2}-14=0 . \text { Tentukan berapa banyak } \\
\text { solusi bilangan real yang dimiliki fungsi tersebut? Apakah ada solusi lain } \\
\text { selain bilangan real? }\end{array}$ \\
\hline
\end{tabular}

Dari 34 mahasiswa Pendidikan Matematika dipilih sebanyak empat mahasiswa secara purposive sampling berdasarkan hasil pekerjaan dengan langkah-langkah penyelesaian yang tidak lengkap atau menunjukkan adanya kesalahan. Data hasil pekerjaan mahasiswa kemudian dianalisis berdasarkan tipe kesalahan menurut Kastolan. Setelah itu dilakukan penarikan kesimpulan atau verifikasi melalui persentase kesalahan secara umum. Kebenaran data dilihat dengan menerapkan teknik triangulasi data yakni membandingkan data hasil tes dan wawancara yang telah dilakukan. Indikator kesalahan yang digunakan dalam penelitian ini diuraikan berdasarkan tipe kesalahan menurut Kastolan yakni kesalahan konseptual, prosedural, dan perhitungan. Berikut ini disajikan uraian penjelasan dari ketiga indikator kesalahan yang diadaptasi dari Meilanawati \& Pujiastuti (2020) pada Tabel 2.

Tabel 2. Indikator Tipe Kesalahan Menurut Kastolan

\begin{tabular}{|c|l|ll|}
\hline No & \multicolumn{1}{|c|}{ Tipe Kesalahan } & \multicolumn{1}{c|}{ Indikator } \\
\hline 1 & Kesalahan Konseptual & 1. $\begin{array}{l}\text { Tidak tepat dalam mengaplikasikan konsep fungsi } \\
\text { polinomial dalam menyelesaikan masalah } \\
\text { Kesalahan dalam menentukan solusi bilangan real } \\
\text { dan imajiner dari persamaan polinomial }\end{array}$ \\
\hline 2 & Kesalahan Prosedural & $\begin{array}{l}\text { 1. } \\
\text { Tidak dapat menyelesaikan soal sampai pada bentuk } \\
\text { yang paling sederhana }\end{array}$ \\
\hline 3 & Kesalahan Teknik & $\begin{array}{l}\text { 1. } \\
\text { Kesalahan dalam melakukan operasi hitung } \\
\text { Kesalahan dalam menentukan hasil akhir }\end{array}$ \\
& 3. $\begin{array}{l}\text { Kesalahan dalam penarikan kesimpulan dari masalah } \\
\text { yang disajikan }\end{array}$ \\
\hline
\end{tabular}

Untuk mengetahui tingkat kesalahan yang dilakukan mahasiswa pada setiap tipe kesalahan maka dilakukan perhitungan persentase kesalahan (P). Selanjutnya ditentukan kategori kesalahan secara umum dengan merujuk pada kategori tingkat kesalahan yang dikemukakan oleh (Sarah, Witri, \& Noviana, 2019).

Tabel 3. Ketegori Persentase Kesalahan

\begin{tabular}{|c|c|}
\hline Persentase (\%) & Kategori Kesalahan \\
\hline$P>55 \%$ & Sangat Berat \\
\hline $40 \%<P \leq 55 \%$ & Berat \\
\hline $25 \%<P \leq 40 \%$ & Cukup Berat \\
\hline $10 \%<P \leq 25 \%$ & Ringan \\
\hline$P \leq 10 \%$ & Sangat Ringan \\
\hline
\end{tabular}

\section{HASIL DAN DISKUSI}

Hasil pekerjaan mahasiswa Pendidikan Matematika yang menunjukkan adanya kesalahan dideskripsikan berdasarkan tipe kesalahan menurut Kastolan yakni kesalahan konseptual, prosedural, dan teknik. Kesalahan konseptual berkaitan dengan kesalahan pengaplikasian konsep fungsi dan persamaan 
polinomial. Kesalahan prosedural berkaitan dengan kesalahan pada langkah-langkah penyelesaian masalah yang disajikan. Sedangkan kesalahan teknik berhubungan dengan kesalahan selama melaksanakan perhitungan untuk menyelesaikan masalah yang disajikan.

Berdasarkan hasil tes pada materi fungsi dan persamaan polinomial, didapatkan adanya kesalahan yang cukup beragam. Terdapat mahasiswa yang melakukan kesalahan teknik saja, ataupun kesalahan teknik dan prosedural saja, bahkan juga ada yang memenuhi seluruh tipe kesalahan yaitu konseptual, prosedural, dan teknik dalam menyelesaikan masalah yang disajikan. Kategori kesalahan mahasiswa dapat dilihat pada Tabel 4 berikut ini.

Tabel 4. Kategori Kesalahan Mahasiswa Berdasarkan Tipe Kesalahan menurut Kastolan

\begin{tabular}{|c|c|c|c|c|c|c|c|}
\hline \multirow{2}{*}{ No } & \multirow{2}{*}{ Tipe Kesalahan } & \multicolumn{3}{|c|}{ Soal } & \multirow{2}{*}{ Total } & \multirow{2}{*}{ Persen } & \multirow{2}{*}{$\begin{array}{c}\text { Kategori } \\
\text { Kesalahan }\end{array}$} \\
\hline & & 1 & 2 & 3 & & & \\
\hline 1. & Kesalahan Konseptual & 17 & 1 & 8 & 26 & $39.4 \%$ & Cukup Berat \\
\hline 2. & Kesalahan Prosedural & 0 & 3 & 8 & 11 & $16.7 \%$ & Ringan \\
\hline 3. & Kesalahan Teknik & 0 & 5 & 24 & 29 & $43.9 \%$ & Berat \\
\hline & Total & 17 & 9 & 40 & 66 & $100 \%$ & \\
\hline
\end{tabular}

Bersumber dari Tabel 3, secara keseluruhan kesalahan yang paling banyak dilakukan oleh mahasiswa adalah kesalahan teknik dengan persentase sebesar $43.9 \%$. Kesalahan teknik berada pada interval $40 \%<P \leq 55 \%$ dan tergolong dalam kategori kesalahan berat. Kesalahan selanjutnya adalah kesalahan konseptual yang dikategorikan sebagai kesalahan cukup berat karena persentase yang diperoleh sebesar $39.4 \%$ berada pada interval $25 \%<P \leq 40 \%$. Kesalahan terkecil yang dilakukan oleh mahasiswa adalah kesalahan prosedural dengan persentase sebesar $16.7 \%$. Persentase kesalahan prosedural berada pada interval $10 \%<P \leq 25 \%$ dan termasuk ke dalam kategori kesalahan ringan.

\section{Kesalahan Konseptual Indikator 1: Tidak tepat dalam mengaplikasikan konsep fungsi polinomial dalam menyelesaikan masalah}

Hasil pekerjaan mahasiswa yang menunjukkan adanya kesalahan konseptual indikator 1 dapat dilihat pada Gambar 1 berikut ini.

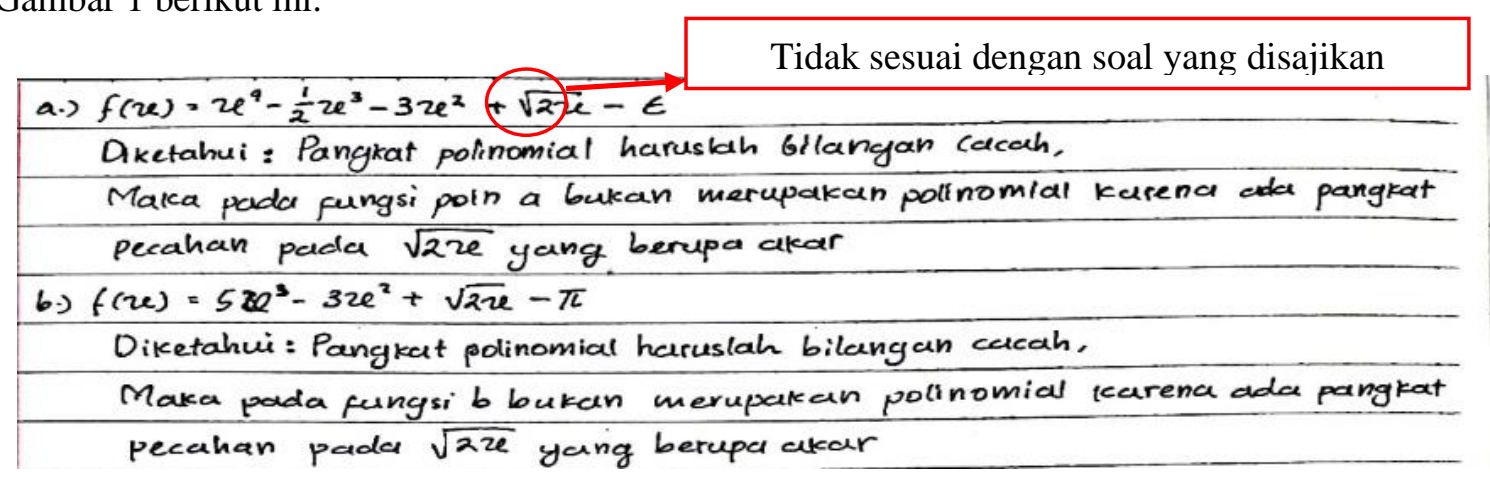

Gambar 1. Hasil Pekerjaan M1 Soal Pertama 
Kesalahan Mahasiswa Pendidikan Matematika dalam Menyelesaikan Masalah Fungsi dan Persamaan Polinomial, Anik Rizka Rahmawati, Sudirman, Rustanto Rahardi

Bersumber dari Gambar 1, terlihat adanya kesalahan yang dilakukan oleh M1. Fungsi yang dituliskan oleh subjek pada tes poin (a) tidak sesuai dengan soal pertama yang disajikan. Hal ini terbukti dari tulisan M1 yang menuliskan $\sqrt{2 x}$ seharusnya $\sqrt{2} x$. Soal pertama disajikan dua buah fungsi yang berbeda pada poin (a) dan (b) dimana subjek diminta untuk menentukan apakah kedua fungsi tersebut merupakan fungsi polinomial atau bukan. Hasil pekerjaan M1 pada poin (a) menghasilkan jawaban yang kurang tepat sebab subjek tidak teliti dalam menuliskan ulang soal yang diberikan. Hal ini diverifikasi peneliti melalui wawancara. Berikut penggalan wawancara peneliti dengan M1.

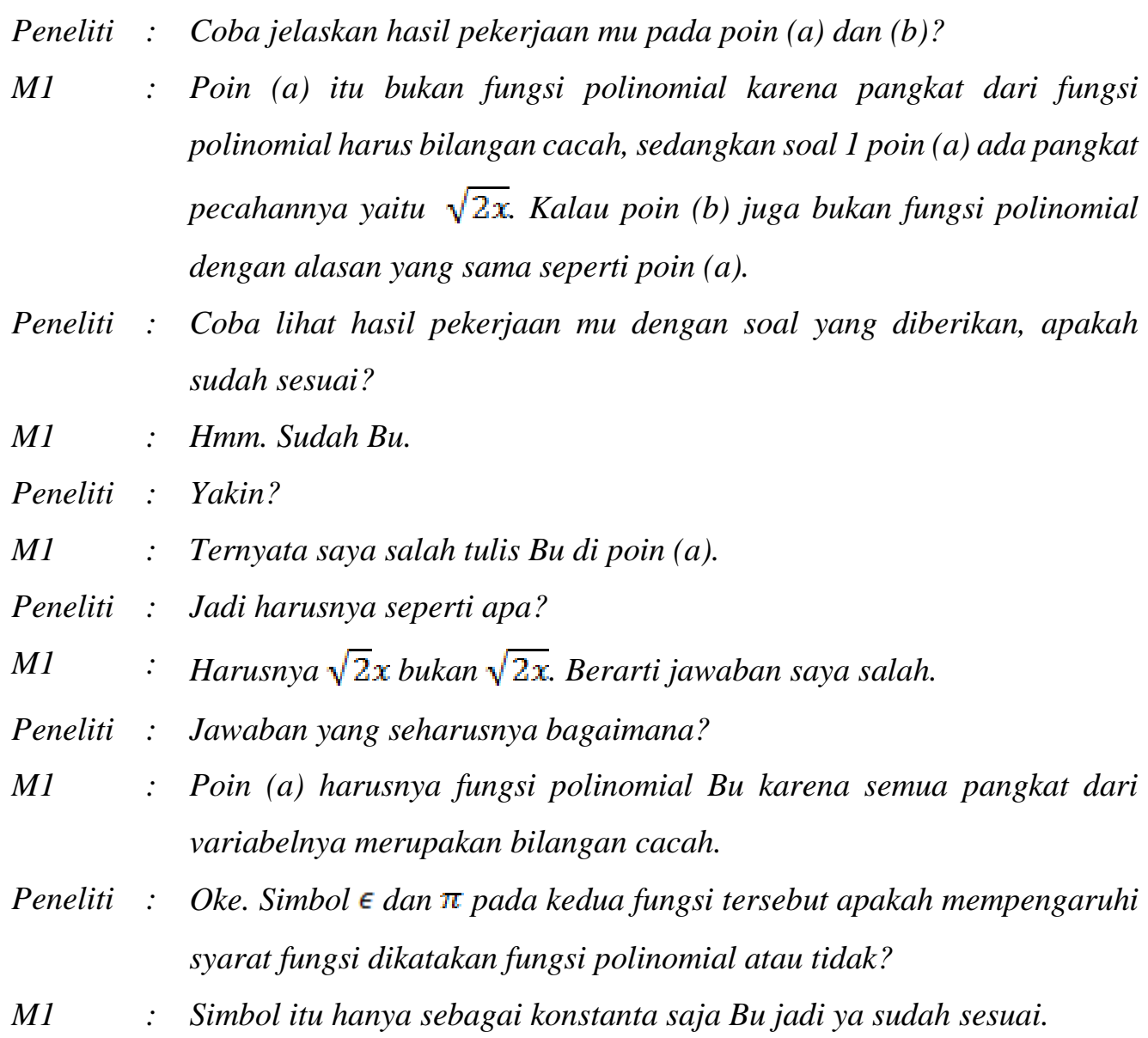

Berdasarkan penggalan wawancara diatas, terlihat M1 kurang cermat dalam memeriksa kesesuaian soal yang dituliskan pada hasil pekerjaannya dengan soal yang diberikan. Hal itu terlihat M1 baru menyadari adanya kesalahan tulis setelah diberi scaffolding oleh peneliti. M1 juga menyadari adanya kesalahan jawaban pada poin (a) sebab M1 mampu menjelaskan jawaban yang tepat untuk soal pertama poin (a). Penyebab kesalahan yang dilakukan oleh M1 karena kurang teliti dalam menuliskan kembali informasi. Konsep suatu fungsi dikatakan fungsi polinomial dapat dikuasai dengan baik setelah dilakukan wawancara.

Kesalahan konseptual terletak ketika subjek tidak tepat dalam mengaplikasikan konsep fungsi polinomial namun ketika dilakukan wawancara, subjek menyadari kesalahannya dan dapat memberikan jawaban yang tepat terkait soal pertama poin (a). Selaras dengan pendapat Mauliandri \& Kartini (2020) bahwa memberikan arahan kepada siswa dapat membantu siswa dalam melakukan perbaikan dari kesalahan yang dilakukannya. Ketidaktelitian menulis kembali informasi yang diperoleh menjadi permasalahan 
sendiri bagi subjek. Serupa dengan pernyataan Veloo, Krishnasamy, \& Wan Abdullah (2015) bahwa kelalaian subjek dalam menyalin informasi juga menjadi alasan utama timbulnya kesalahan. Menurut Boonen, Koning, Jolles, \& Schoot (2016) keterampilan individu dalam membaca teks matematika menjadi hal yang penting dalam keberhasilan menyelesaikan masalah.

\section{Kesalahan Konseptual Indikator 2: Kesalahan dalam menentukan solusi bilangan real dan imajiner dari persamaan polinomial}

Berikut ini disajikan hasil pekerjaan mahasiswa yang termasuk ke dalam kesalahan konseptual indikator 2.

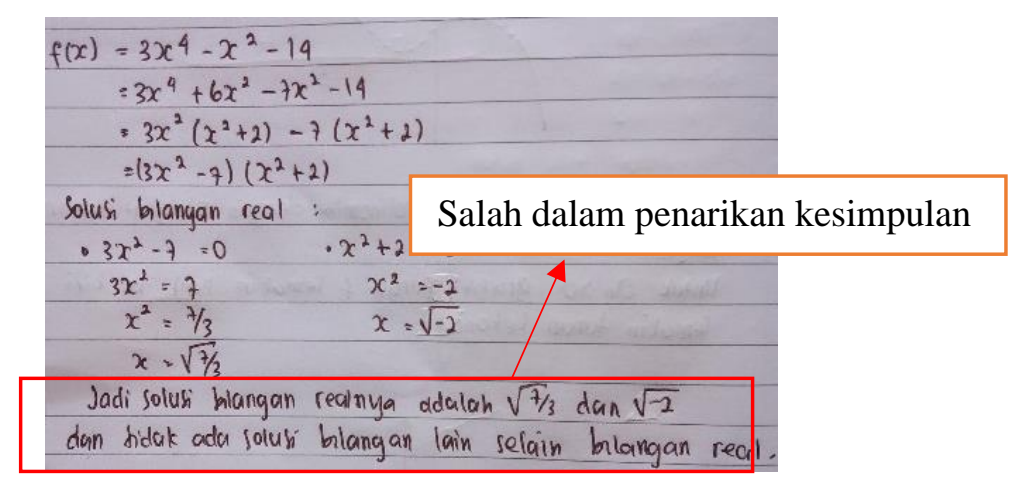

Gambar 2. Hasil Pekerjaan M2 Soal Ketiga

Bersumber dari hasil pekerjaan subjek M2, terlihat bahwa M2 melakukan kesalahan pada bagian penarikan kesimpulan. Meskipun terletak pada bagian kesimpulan akan tetapi kesalahan yang dilakukan M2 termasuk ke dalam kesalahan konseptual indikator 2 yakni adanya kesalahan dalam menentukan solusi bilangan real dan imajiner dari persamaan polinomial. M2 hanya berfokus pada solusi akhir yakni solusi real sehingga juga menggolongkan $\sqrt{-2}$ sebagai solusi real dari persamaan yang diberikan dan juga menyatakan bahwa tidak ada solusi lain selain bilangan real. Hal ini menandakan adanya kesalahan konsep terkait perbedaan bilangan real dan imajiner yang membuat hasil akhir menjadi tidak tepat. Hal ini juga diperkuat melalui wawancara. Berikut cuplikan wawancara M2 dengan peneliti.

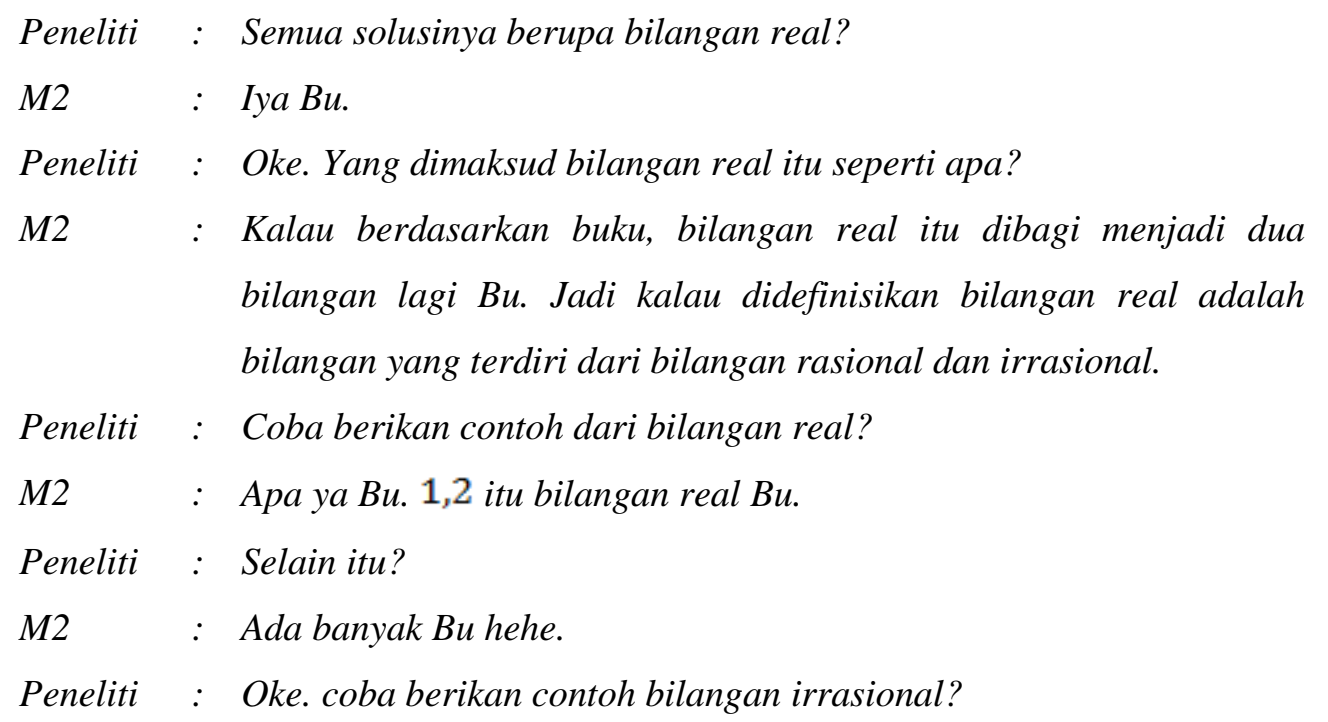


Kesalahan Mahasiswa Pendidikan Matematika dalam Menyelesaikan Masalah Fungsi dan Persamaan Polinomial, Anik Rizka Rahmawati, Sudirman, Rustanto Rahardi

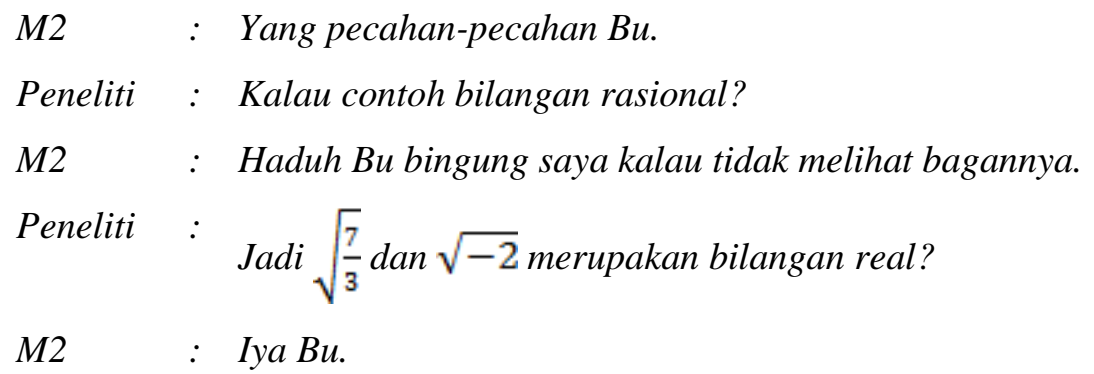

Merujuk dari cuplikan wawancara di atas, M2 meyakini bahwa solusi yang didapatkannya sudah tepat namun solusi yang dituliskannya menunjukkan adanya ketidaktepatan dalam hal konsep bilangan real dan imajiner. Saat di wawancara, M2 mampu menjelaskan pengertian dari bilangan real berdasarkan buku yang telah dipelajarinya. M2 juga mampu menyebutkan contoh dari bilangan real yakni 1 dan 2, namun ketika M2 diminta untuk menyebutkan contoh selain itu, Ia mengungkapkan bahwa ada banyak bilangan yang termasuk bilangan real. Peneliti kemudian mengulik lebih dalam tentang bilangan rasional dan irrasional. M2 kurang mampu menguasai konsep bilangan rasional dan irrasional sebab M2 keliru menyebutkan contoh dari bilangan irrasional, yang seharusnya merupakan contoh dari bilangan rasional yakni pecahan. Selain itu, M2 juga mengaku kebingungan karena tidak melihat bagan/skema dari bilangan real ketika ditanya lebih detail tentang bilangan rasional dan irrasional. Bersumber dari uraian di atas, dapat dikatakan bahwa M2 kurang mampu menguasai konsep bilangan real dengan baik sebab tidak menyadari bahwa $\sqrt{-2}$ bukan solusi real melainkan solusi imajiner.

Pengetahuan yang dimiliki oleh mahasiswa sering tertukar dalam membedakan solusi real dan imajiner. Kesalahan konseptual akan terjadi jika lemahnya penguasaan materi prasyarat sebelum melangkah ke materi selanjutnya (Rismawati \& Asnayani, 2019). Merujuk pada hasil, kurangnya pengetahuan tentang skema bilangan real membuat kesimpulan akhir tidak sesuai dengan perintah soal. Oleh karena itu, Angateeah (2017) berpendapat bahwa pengetahuan dasar merupakan salah satu faktor yang diperlukan untuk menyelesaikan suatu masalah. Mendukung hal tersebut, Kapur (2014) mengemukakan bahwa adanya pengetahuan awal (prior knowledge) dapat memberikan peluang lebih besar untuk membandingkan solusi yang dihasilkan oleh peserta didik dan solusi yang benar sehingga membantu peserta didik dalam menghasilkan konsep baru.

\section{Kesalahan Prosedural Indikator 1: Tidak dapat menyelesaikan soal sampai pada bentuk yang paling sederhana}

Berikut ini disuguhkan hasil pekerjaan mahasiswa yang menunjukkan adanya kesalahan prosedural indikator 1 pada gambar 3. Bersumber dari Gambar 3, M3 melakukan kesalahan prosedural indikator 1 yaitu tidak dapat menyelesaikan soal sampai pada bentuk yang paling sederhana. Soal kedua diminta untuk mencari panjang dan lebar dari aquarium yang berbentuk balok. Namun M3 memberikan jawaban untuk ukuran panjang dan lebar masih dalam bentuk fungsi kuadrat. Bentuk fungsi kuadrat seharusnya dapat disederhanakan dengan melakukan pemfaktoran dan didapatkan hasil akhir yakni $(3 x+5)$ dan $(2 x+3)$ 
sebagai ukuran panjang dan lebar aquarium. Hal itu M3 dapat dikatakan belum tepat memberikan hasil akhir yang diminta pada soal kedua.

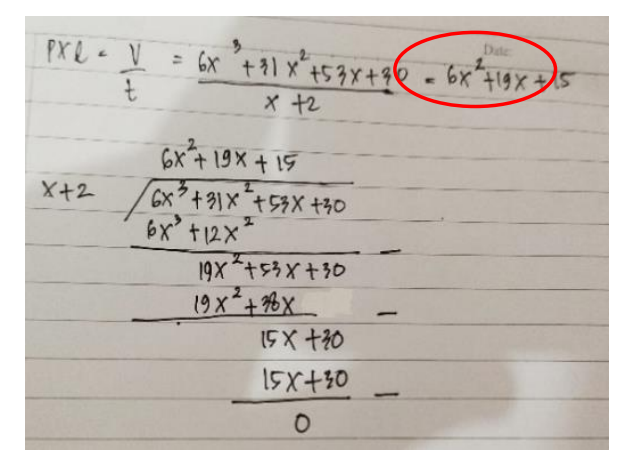

Gambar 3. Hasil Pekerjaan M3 Soal kedua

Peneliti juga melakukan konfirmasi melalui wawancara dengan M3 sebagai berikut.

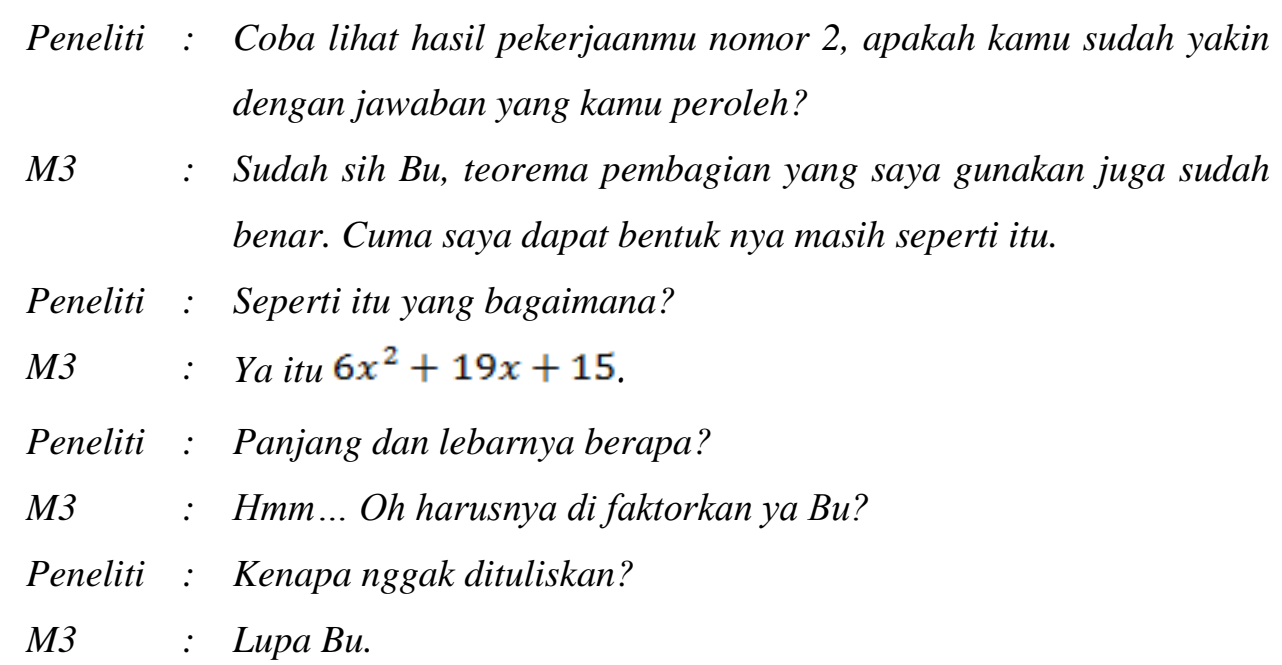

Berdasarkan dari hasil pekerjaan M3 dan wawancara di atas, M3 tidak dapat menuliskan hasil akhir ke dalam bentuk yang paling sederhana. Terlihat dari pernyataan M3 yang menyadari bahwa seharusnya dilakukan pemfaktoran untuk mencari panjang dan lebar aquarium namun Ia tidak melaksanakan langkah tersebut akibat lupa. Bersumber dari uraian di atas, hasil akhir yang dicapai oleh M3 masih kurang tepat karena hasil tidak sesuai dengan instruksi pada soal kedua. Kesalahan prosedural muncul karena ketidakmampuan mahasiswa dalam melakukan manipulasi saat menyelesaikan masalah meskipun telah memahami konsep dibalik masalah yang diberikan (Meilanawati \& Pujiastuti, 2020). Hal ini mengakibatkan subjek tidak mencapai hasil akhir yang diperintahkan soal.

\section{Kesalahan Teknik Indikator 1,2, dan 3: Kesalahan dalam melakukan operasi hitung, hasil akhir, dan penarikan kesimpulan dari masalah yang disajikan}

Hasil pekerjaan mahasiswa berikut ini termasuk ke dalam kesalahan teknik yang memenuhi ketiga indikator. 


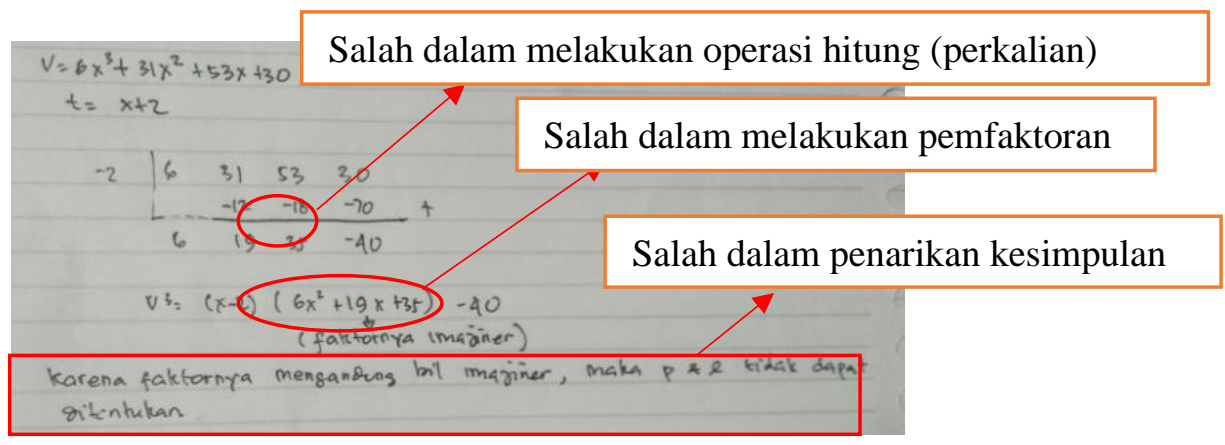

Gambar 4. Hasil Pekerjaan M4 Soal Kedua

Bersumber dari hasil pekerjaan M4, terdapat tiga kesalahan yang dilakukan oleh M4 yakni salah dalam melakukan operasi hitung perkalian dan pemfaktoran yang berakibat salah dalam penarikan kesimpulan. Kesalahan yang dilakukan M4 termasuk ke dalam kesalahan teknik yang memenuhi seluruh indikator 1 sampai 3. M4 mampu menguasai konsep skema horner dengan tepat namun melakukan kesalahan perhitungan yang mengakibatkan sisa pembagian tidak bernilai 0 yakni -40 . M4 juga mendapatkan hasil pembagian suku banyak (fungsi polinomial) oleh $(x+2)$ yakni $6 x^{2}+19 x+35$ namun M4 menuliskan bahwa hasil pembagian tersebut mempunyai faktor imajiner. Hal ini juga dikonfirmasi peneliti saat wawancara. Berikut penggalan wawancara peneliti dengan M4.

\section{Peneliti : Apakah kamu merasa kesulitan mengerjakan soal kedua? \\ M4 : Kesulitan sih nggak Bu. Cuma ada yang aneh aja sama jawaban saya. \\ Peneliti : Merasa aneh di bagian mana? \\ M4 : Hasil pembagian yang saya dapatkan memiliki faktor-faktor imajiner. Sehingga karena mengandung bilangan imajiner jadi panjang dan lebarnya nggak bisa ditentukan. Nah anehnya karena mengandung bilangan imajiner.}

Berdasarkan wawancara di atas, M4 tidak merasa kesulitan untuk menyelesaikan soal kedua. Hanya saja M4 merasa ada yang janggal dari hasil pekerjaannya karena faktor yang didapatkan dari hasil pembagian berupa bilangan imajiner. Hal ini konsep pemfaktoran tidak dikuasai oleh M4 dengan baik. Seharusnya faktor dari $6 x^{2}+19 x+35$ adalah $(3 x+5)$ dan $(2 x+3)$ dengan nilai $x \in \mathbb{R}$. Jawaban akhir terkait panjang dan lebar aquarium masih tidak tepat sebab M4 tidak dapat menentukan ukuran panjang dan lebar sesuai dengan instruksi soal.

Kesalahan teknik pada penelitian ini berupa kesalahan subjek dalam melakukan operasi hitung perkalian, tidak dapat melaksanakan langkah pemfaktoran, dan berimbas pada penarikan kesimpulan yang tidak tepat. Hal ini sependapat dengan Anugrahana (2020) bahwa terdapat beberapa faktor mahasiswa sering melakukan kesalahan salah satunya yakni mahasiswa tidak teliti dalam mengoperasikan operasi hitung bilangan bulat. 


\section{KESIMPULAN}

Kesalahan yang paling dominan terletak pada kesalahan teknik dengan persentase sebesar $43.9 \%$ dan dikategorikan sebagai kesalahan yang berat. Hal ini dikarenakan hampir separuh dari mahasiswa melakukan kesalahan dalam hal perhitungan. Kesalahan berikutnya adalah kesalahan konseptual dengan persentase sebesar 39.4\%. Kesalahan dikategorikan cukup berat karena konsep yang dimiliki oleh mahasiswa menunjukkan kesalahan dari konsep fungsi polinomial (suku banyak) dan skema bilangan real. Kesalahan dengan kategori ringan adalah kesalahan prosedural dengan persentase sebesar $16.7 \%$. Hal ini sesuai dengan keadaan lapangan bahwa terdapat hasil pekerjaan mahasiswa yang tidak menuliskan hasil akhir dalam bentuk paling sederhana sehingga menyebabkan jawaban akhir tidak sesuai dengan perintah soal. Hasil penelitian ini diharapkan dapat menjadi masukkan oleh pendidik agar bisa memberikan perhatian terhadap kesalahan-kesalahan yang dilakukan mahasiswa sehingga tidak terjadi kesalahan secara berulang.

\section{UCAPAN TERIMA KASIH}

Peneliti mengucapkan terima kasih kepada kedua dosen pembimbing Bapak Dr. Sudirman, M. Si, dan Bapak Dr. Rustanto Rahardi, M.Si., yang telah memberikan bimbingan serta arahan dalam proses penyusunan artikel. Ucapan terima kasih selanjutnya peneliti tujukan kepada kedua orang tua dan para sahabat yang telah memberikan motivasi dan semangat tiada hentinya.

\section{REFERENSI}

Angateeah, K. S. (2017). An Investigation of Students' Difficulties in Solving Non-Routine Word Problem at Lower Secondary. International Journal of Learning and Teaching, 3(1), 46-50. https://doi.org/10.18178/ijlt.3.1.46-50

Anugrahana, A. (2020). Analisis Kesalahan Matematika Konsep Operasi Hitung Bilangan Bulat Mahasiswa Calon Guru Sekolah Dasar. Sigma, 5(2), 91. https://doi.org/10.36513/sigma.v5i2.791

Arilaksmi, N. P. G., Susiswo, \& Sulandra, I. M. (2021). Kemampuan Pemecahan Masalah Open-Ended Siswa SMP Berdasarkan Tahapan Polya. VYGOTSKY, 3(1), 1-12.

Boonen, A. J. H., Koning, B. B. De, Jolles, J., \& Schoot, M. Van Der. (2016). Word Problem Solving in Contemporary Math Education: A Plea for Reading Comprehension Skills Training. Frontiers in Psychology, 7(February), 1-10. https://doi.org/10.3389/fpsyg.2016.00191

Febriyanti, R. (2019). Pola Pemecahan Masalah Matematika pada Siswa yang Berkemampuan Setara. VYGOTSKY, 1(2), 56-64.

Firdaus, E. F., Amalia, S. R., \& Zumeira, A. F. -. (2021). Analisis Kesalahan Siswa Berdasarkan Tahapan Kastolan dalam Menyelesaikan Soal Matematika. Jurnal Pendidikan Matematika, 8(1), 542-558.

Hasratuddin. (2014). Pembelajaran Matematika Sekarang dan yang akan Datang Berbasis Karakter. Jutnal Didaktik Matematika, 1(2), 30-42. 
Jupri, A., \& Drijvers, P. (2016). Student difficulties in mathematizing word problems in Algebra. Eurasia Journal of Mathematics, Science and Technology Education, 12(9), 2481-2502. https://doi.org/10.12973/eurasia.2016.1299a

Kapur, M. (2014). Productive failure in learning math. Cognitive Science, 38(5), 1008-1022. https://doi.org/10.1111/cogs.12107

Mauliandri, R., \& Kartini. (2020). Analisis Kesalahan Siswa Menurut Kastolan dalam Menyelesaikan Soal Operasi Bentuk Aljabar pada Siswa SMP. Axiom: Jurnal Pendidikan Dan Matematika, 09(2), 107123.

Meilanawati, P., \& Pujiastuti, H. (2020). Analisis Kesalahan Mahasiswa Mengerjakan Soal Teori Bilangan Menurut Tahap Kastolan Ditinjau dari Gender. Jurnal Pendidikan Matematika STKIP Bina Bangsa Meulaboh, 7(2), 182-190.

Musyadad, V. F. (2021). Analisis Kesalahan Mahasiswa PGMI dalam Menyelesaikan Soal Matematika Menurut Teori Kastolan. Edumaspul: Jurnal Pendidikan, 5(1), 203-207. Retrieved from https://ummaspul.e-journal.id/maspuljr/article/view/1132

Noviani, J. (2019). Analisis Kesalahan Tahapan Kastolan Dan Pemecahan Masalah Model Polya Pada Mata Kuliah Matematika Finansial. Jurnal Ilmiah Pendidikan Matematika Al Qalasadi, 3(1), 27-39. https://doi.org/10.32505/qalasadi.v3i1.891

Raharti, A. D., \& Yunianta, T. N. H. (2020). Identifikasi Kesalahan Matematika Siswa SMP Berdasarkan Tahapan Kastolan. Journal of Honai Math, 3(1), 77-100. https://doi.org/10.30862/jhm.v3i1.114

Rismawati, M., \& Asnayani, M. (2019). Analisis Kesalahan Konsep Siswa Dalam Menyelesaikan Soal Ulangan Matematika Dengan Metode Newman. J-PiMat : Jurnal Pendidikan Matematika, 1(2), 6978. https://doi.org/10.31932/j-pimat.v1i2.495

Romadiastri, Y. (2012). Analisis Kesalahan Mahasiswa Matematika dalam Menyelesaikan Soal- Soal Logika. PHENOMENON, 2(1), 75-93.

Sarah, S., Witri, G., \& Noviana, E. (2019). Analisis Kesalahan Siswa dalam Menyelesaikan Soal Bilangan Pecahan Berdasarkan Tipe Kesalahan Nolthing Kelas V Se-Gugus 1 Kecamatan Tampan Kota Pekanbaru. JOM FKIP, 6(1), 1-9.

Ulfa, D., \& Kartini, K. (2021). Analisis Kesalahan Siswa dalam Menyelesaikan Soal Logaritma Menggunakan Tahapan Kesalahan Kastolan. Jurnal Cendekia : Jurnal Pendidikan Matematika, 5(1), 542-550. https://doi.org/10.31004/cendekia.v5i1.507

Veloo, A., Krishnasamy, H. N., \& Wan Abdullah, W. S. (2015). Types of student errors in mathematical symbols, graphs and problem-solving. Asian Social Science, 11(15), 324-334. https://doi.org/10.5539/ass.v11n15p324. 